\title{
SCENARIO OF INSECT PESTS, PREDATORS AND POLLINATORS ASSOCIATED WITH CROP PLANTS IN AN AGROFORESTRY IN BANGLADESH
}

\author{
M.R. Mia ${ }^{1}$, M.R. Amin ${ }^{1}$, H. Rahman ${ }^{1}$ and M.G. Miah ${ }^{2}$ \\ ${ }^{1}$ Department of Entomology, Bangabandhu Sheikh Mujibur Rahman Agricultural University \\ Gazipur, Bangladesh \\ ${ }^{2}$ Department of Agroforestry and Environment, Bangabandhu Sheikh Mujibur Rahman \\ Agricultural University, Gazipur, Bangladesh
}

\begin{abstract}
The abundance of insect pests, predators and pollinators and status of pest insects associated with citrus, mango and pineapple crops grown in an agroforestry in Bangladesh was studied during July 2015 to June 2016. Twenty five species of insects belonging to 19 families in 5 orders were found as pest of citrus and their relative abundance varied from 2.4 to $13.4 \%$. Among the citrus pests, green leaf hopper was most abundant, but whitefly, mealy bug, lemon butterfly and leaf minor were found as major pests. Fifteen species of insects under 13 families in 6 orders were found as pests of mango and their relative abundance varied from 0.5 to $82.6 \%$, and hopper and fruit fly were found as major pests. Four species of insects belonging to 4 families in 3 orders were found as pest of pineapple and their relative abundance varied from 12.2 to $44.9 \%$, and all were found as minor pests. There were 20 species of predator insects belonging to 13 families in 6 orders and their abundance ranged from 0.8 to $2.5 / 40$ sweeps. In total 19 species of insects belonging to 12 families in 4 orders were found as pollinators and their abundance varied from 1.7 to $5.1 / 40$ sweeps. The ants and honeybees were most abundant as predators and pollinators, respectively.
\end{abstract}

Keywords: Agroforestry, Abundance, Insect Species, Citrus, Mango, Pineapple

\section{INTRODUCTION}

Bangladesh is a subtropical country having an area of $147570 \mathrm{~km}^{2}$ with 160.2 million people. Agriculture has an overwhelming impact on the economy of the nation and has made significant progress in boosting national food production. However, a large part of the population still lacks access to sufficient, safe, and nutritious food. Arable land and forest areas in Bangladesh are reducing day by day due to demographic

\footnotetext{
*Corresponding author: mramin.bsmrau@gmail.com
} 
pressure, urbanization and industrialization. To accelerate crop production and conservation of nature, the concept of agrofrorestry has become popular here in the recent decades.

Agroforsetry is an agricultural system comprising diversity of plants, pests, predators and pollinators which are linked to crop productivity. Intensive agricultural system creates disturbance of the natural habitats, and affects species richness, abundance and community structure (Debinski and Holt, 2000). That is why the cultivated areas in Bangladesh are gaining interest for conserving tropical biodiversity.

The diversity of crop species in the agroforestry provides a variety of resources like shelter and food for predators and pollinators. The heterogeneity of the habitat in the agroforestry area thus alters the quality and quantity of bio-resources and regulates ecological niches of various species in the community (Bugg and Waddington, 1994). The composition of an agroforestry system influences its microclimatic factors such as temperature, relative humidity, light intensity, precipitation, wind, carbon dioxide and water vapor thereby affecting on the diversity and abundance of insect species (Dwivedi et al., 2003; Anitha et al., 2009).

Mango, pineapple and citrus are popular fruits in Bangladesh and these crops are widely grown throughout the country. In the agroforestry system, pineapple, citrus and mango are cultivated as lower, middle and upper storied crop, respectively, but there is limited information regarding insect abundance and their nature of interactions with these crops. Therefore, in the present study, the abundance of insect pests, predators and pollinators, status of insect pests associated with citrus, mango and pineapple were taken into investigation.

\section{MATERIALS AND METHODS}

\section{Study site and condition}

The study was conducted in the agroforestry field laboratory of Bangabandhu Sheikh Mujibur Rahman Agricultural University (BSMRAU) at Gazipur $\left(25^{\circ} 25^{\prime}\right.$ North latitude and $89^{\circ} 5^{\prime}$ East longitude) in Bangladesh during July 2015 to June 2016. The study site is surrounded by sal (Shorea robusta) forest. The climate of this area is characterized as dry during February to May, rainy from June to September, and cold from December to January. Annual mean maximum and minimum temperatures are $36.0^{\circ} \mathrm{C}$ and $12.7^{\circ} \mathrm{C}$, respectively, with $65.8 \%$ relative humidity and $237.6 \mathrm{~cm}$ rainfall. The agroforestry system is marked by different management intensity, grasslands, rice, fruit and vegetable crops. The area of the agroforestry is $2205 \mathrm{~m}^{2}$, and occupied by citrus, pineapple and 45 mango trees (variety Amrapali); each 11 years old, 3-4 m high and $7 \mathrm{~m}$ apart.

\section{Insect collection and identification}

The free-living insects on citrus, pineapple and mango plants were collected during the day using a $30 \mathrm{~cm}$ diameter sweep net having $1.5 \mathrm{~mm}$ mesh and attached with a 
$2.0 \mathrm{~m}$ long rod. Sweeping was done in between 10.00 and 11.30 hour of the day every two weeks interval and each sample consisted of 40 sweeps, encompassing an area from ground level to the top of the trees. Small and immobile insects were observed by collecting infested leaves. The collected insects and leaves were brought from the experiment field to the Entomology Laboratory of BSMRAU for counting total catch. The insects were killed by storing in a freezer for one night, then mounted on points and dried and morphotyped. During each sampling, sessile insects were observed and identified using hand lens on 40 leaves of each crop. Insects were identified by observing their morphological characteristics, compared with museum specimens and with photographs to species or genus level and also separated as pest, predator and pollinator.

\section{Assessment of pest status}

During insect collection, leaf, flower and fruit of citrus, mango and pineapple were observed for infestation (\%) of different insect pests. Insects those caused less than $10 \%$ infestation were categorized as minor pest, while those with $10 \%$ or above infestation were categorized as major pests.

\section{Calculation of relative abundance and statistical analysis}

Relative abundance (\%) of the pest species of citrus, mango and pineapple was calculated using the following formula.

$$
\text { Abundance }(\%)=\frac{\text { Total number of individual of a species }}{\text { Total number of individual of different species }} \times 100
$$

One way analysis of variance (ANOVA) followed by Tukey post hoc statistics was employed for analyzing the data of the predator and pollinator species. All the analyses were performed using IBM SPSS 21.0. (IBM SPSS statistics 21, Georgia, USA).

\section{RESULTS AND DISCUSSION}

In total 25 species of insects belonging to 19 families in 5 orders (Isoptera, Thysanoptera, Hemiptera, Lepidoptera and Diptera) were found as pest of citrus (Table 1). Their relative abundance varied from 2.4 to $13.4 \%$, and green leaf hopper was most abundant $(13.4 \%)$ followed by mealy bug $(9.3 \%)$, leaf miner $(8.6 \%)$, fruit fly $(7.4 \%)$ and lemon butter fly (7.2\%). The percent abundance of the other insects was less than $5.0 \%$. Among the insects, white fly, mealy bug, lemon butterfly and leaf minor were found as major pest as they caused more than $10 \%$ infestation, and the other insects were found as minor pest because their infestation level was less than $10 \%$. 
Table 1. Taxonomic profile, comparative abundance and status of pest insects associated with citrus plant in the agroforestry area during July 2015 to June 2016

\begin{tabular}{|c|c|c|c|}
\hline Name & Taxonomic profile & $\begin{array}{l}\text { Abundance } \\
\qquad \%)\end{array}$ & Status \\
\hline Termite & $\begin{array}{l}\text { Odontotermes obesus Ramber (Isoptera: } \\
\text { Termitidae) }\end{array}$ & 4.5 & Minor \\
\hline Thrips & $\begin{array}{l}\text { Scirtothrips citri Moulton (Thysanoptera: } \\
\text { Thripidae) }\end{array}$ & 4.8 & Minor \\
\hline White fly & $\begin{array}{l}\text { Dialeurodes citri Ashmead (Hemiptera: } \\
\text { Aleyrodidae) }\end{array}$ & 5.3 & Major \\
\hline Black fly & $\begin{array}{l}\text { Aleurocanthus woglumi Ashby (Hemiptera: } \\
\text { Aleyrodidae) }\end{array}$ & 2.6 & Minor \\
\hline Black aphid & $\begin{array}{l}\text { Toxoptera aurantii Boyer De Fonscolombe } \\
\text { (Hemiptera: Aphididae) }\end{array}$ & 4.3 & Minor \\
\hline Scale insect & $\begin{array}{l}\text { Ceroplastes destructor Newstead (Hemiptera: } \\
\text { Coccidae) } \\
\text { Aonidiella aurantii Maskell (Hemiptera: } \\
\text { Diaspididae) } \\
\text { Aonidiella citrina Coquillett (Hemiptera: } \\
\text { Diaspididae) } \\
\text { Icerya purchase Maskell (Hemiptera: } \\
\text { Margarodidae) }\end{array}$ & $\begin{array}{c}5.0 \\
- \\
- \\
-\end{array}$ & Minor \\
\hline Mealy bug & $\begin{array}{l}\text { Planococcus citri Risso (Hemiptera: } \\
\text { Pseudococcidae) } \\
\text { Pseudococcus citriculus Green (Hemiptera: } \\
\text { Pseudococcidae) } \\
\text { Pseudococcus filamentosus Cockrell } \\
\text { (Hemiptera: Pseudococcidae) }\end{array}$ & $\begin{array}{c}9.3 \\
- \\
-\end{array}$ & Major \\
\hline Spined bug & $\begin{array}{l}\text { Biprorulus bibax Breddin (Hemiptera: } \\
\text { Pentatomidae) }\end{array}$ & 2.6 & Minor \\
\hline Citrus psyllid & $\begin{array}{l}\text { Diaphorina citri Kuwayama (Hemiptera: } \\
\text { Psyllidae) }\end{array}$ & 4.8 & Minor \\
\hline $\begin{array}{l}\text { Green leaf } \\
\text { hopper }\end{array}$ & $\begin{array}{l}\text { Empoasca citrusa Theron (Hemiptera: } \\
\text { Cicadellidae) }\end{array}$ & 13.4 & Minor \\
\hline Leaf-footed bug & $\begin{array}{l}\text { Leptoglossus phyllopus Linnaeus (Hemiptera: } \\
\text { Coreidae) }\end{array}$ & 2.6 & Minor \\
\hline Green stink bug & $\begin{array}{l}\text { Rhynchocorris humeralis Thunberg (Hemiptera: } \\
\text { Pentatomidae) }\end{array}$ & 4.1 & Minor \\
\hline $\begin{array}{l}\text { Bark-eating } \\
\text { borer }\end{array}$ & $\begin{array}{l}\text { Indrabela quadrinotata Walker (Lepidoptera: } \\
\text { Metarbelidae) }\end{array}$ & 2.6 & Minor \\
\hline
\end{tabular}




\begin{tabular}{|c|c|c|c|}
\hline Name & Taxonomic profile & $\begin{array}{l}\text { Abundance } \\
(\%)\end{array}$ & Status \\
\hline $\begin{array}{l}\text { Fruit piercing } \\
\text { moth }\end{array}$ & Othreis cjeta Cramer (Lepidoptera: Noctuidae) & 3.4 & Minor \\
\hline Lemon butterfly & $\begin{array}{l}\text { Papilio demoleus Linnaeus (Lepidoptera: } \\
\text { Papilionidae) }\end{array}$ & 7.2 & Major \\
\hline $\begin{array}{l}\text { Swallow tail } \\
\text { butter fly }\end{array}$ & $\begin{array}{l}\text { Papilio polytis Linnaeus (Lepidoptera: } \\
\text { Papilionidae) }\end{array}$ & 2.6 & Minor \\
\hline Leaf miner & $\begin{array}{l}\text { Phyllocnistis citrella Stainton (Lepidoptera: } \\
\text { Gracillaridae) }\end{array}$ & 8.6 & Major \\
\hline Flower moth & $\begin{array}{l}\text { Prays citri Milliere (Lepidoptera: } \\
\text { Yponomeutidae) }\end{array}$ & 2.4 & Minor \\
\hline Rrind borer & $\begin{array}{l}\text { Prays endocarpa Meyrick (Lepidoptera: } \\
\text { Yponomeutidae) }\end{array}$ & 2.4 & Minor \\
\hline Fruit fly & $\begin{array}{l}\text { Bactrocera dorsalis Hendel (Diptera: } \\
\text { Tephritidae) }\end{array}$ & 7.4 & Minor \\
\hline
\end{tabular}

Fifteen species of insects under 13 families in 6 orders (Isoptera, Thysanoptera, Hemiptera, Coleoptera, Lepidoptera and Diptera) were found as pest of mango (Table 2 ). Their relative abundance varied from 0.5 to $82.6 \%$, and mango hopper was the most abundant $(82.6 \%)$ followed by fruit fly $(8.0 \%)$. The mango hopper and fruit fly were found as major pest because their infestation level was more than $10 \%$.

Table 2. Taxonomic profile, comparative abundance and status of pest insects associated with mango plant in the agroforestry area during July 2015 to June 2016

\begin{tabular}{l|l|c|c}
\hline Name & Taxonomic profile & $\begin{array}{c}\text { Abundance } \\
(\%)\end{array}$ & Status \\
\hline Termite & $\begin{array}{l}\text { Odontotermes obesus Ramber (Isoptera: } \\
\text { Termitidae) }\end{array}$ & 0.72 & Minor \\
Thrips & $\begin{array}{l}\text { Thrips hawaiiensis Morgan (Thysanoptera: } \\
\text { Thripidae) }\end{array}$ & 0.8 & Minor \\
& $\begin{array}{l}\text { Idioscopus clypealis Lethierry (Hemiptera: } \\
\text { Cicadellidae) }\end{array}$ & 82.6 & Major \\
& $\begin{array}{l}\text { Idioscopus niveosparus Lethierry (Hemiptera: } \\
\text { Cicadellidae) }\end{array}$ & - & \\
& $\begin{array}{l}\text { Amritodus atkinsoni Lethierry (Hemiptera: } \\
\text { Cicadellidae) }\end{array}$ & & \\
Mealy bug & $\begin{array}{l}\text { Rostrococcus iceryoides Green (Hemiptera: } \\
\text { Pseudococcidae) }\end{array}$ & 1.5 & Minor \\
\hline
\end{tabular}




\begin{tabular}{|c|c|c|c|}
\hline Name & Taxonomic profile & $\begin{array}{l}\text { Abundance } \\
(\%)\end{array}$ & Status \\
\hline Scale insect & $\begin{array}{l}\text { Aulacaspis tubercularis Newstead (Hemiptera: } \\
\text { Coccidae) }\end{array}$ & 0.5 & Minor \\
\hline Stem borer & $\begin{array}{l}\text { Bactocera rufomaculata De Geer (Coleoptera: } \\
\text { Cerambycidae) }\end{array}$ & 0.8 & Minor \\
\hline Stone weevil & $\begin{array}{l}\text { Sternochaetus mangiferae Fabricius } \\
\text { (Coleoptera: Curculionidae) }\end{array}$ & 0.9 & Minor \\
\hline $\begin{array}{l}\text { Mango } \\
\text { defoliator }\end{array}$ & $\begin{array}{l}\text { Cricula trifenestrata Helfer (Lepidoptera: } \\
\text { Saturniidae) }\end{array}$ & 0.9 & Minor \\
\hline $\begin{array}{l}\text { Bark eating } \\
\text { caterpillar }\end{array}$ & $\begin{array}{l}\text { Indarbella quadrinotata Walker (Lepidoptera: } \\
\text { Noctuidae) }\end{array}$ & 0.7 & Minor \\
\hline Leaf webber & $\begin{array}{l}\text { Orthaga exvinacea Hampson (Lepidoptera: } \\
\text { Pyralidae) }\end{array}$ & 1.0 & Minor \\
\hline $\begin{array}{l}\text { Leaf eating } \\
\text { caterpillar }\end{array}$ & $\begin{array}{l}\text { Euthalia garuda Moore (Lepidoptera: } \\
\text { Nymphalidae) }\end{array}$ & 1.1 & Minor \\
\hline Fruit fly & Daucas dorsalis Hendel (Diptera: Tephritidae) & 8.0 & Major \\
\hline Leaf gall & $\begin{array}{l}\text { Procontarinia matteiana Kieffer \& Cecconi } \\
\text { (Diptera: Cecidomyiidae) }\end{array}$ & 0.5 & Minor \\
\hline
\end{tabular}

Table 3 showed that four species of insects belonging to 4 families were found as pest of pineapple. Their relative abundance varied from 12.2 to $44.9 \%$, and the mealy bug was most abundant followed by fruit borer, black spot beetle and midget. The infestation levels of the insect species were less than $10 \%$ and all of them were termed as minor pest.

Table 3. Taxonomic profile, comparative abundance and status of pest insects associated with pineapple plant in the agroforestry area during July 2015 to June 2016

\begin{tabular}{|c|c|c|c|}
\hline Name & Taxonomic profile & $\begin{array}{l}\text { Abundance } \\
(\%)\end{array}$ & Status \\
\hline Mealy bug & $\begin{array}{l}\text { Dysmicoccus brevipes Cockerell (Hemiptera: } \\
\text { Pseudococcidae) }\end{array}$ & 44.9 & Minor \\
\hline $\begin{array}{l}\text { Black spot } \\
\text { beetle }\end{array}$ & $\begin{array}{l}\text { Metamasius dimidiatipennis Jekel } \\
\text { (Coleoptera:Curculionidae) }\end{array}$ & 18.4 & Minor \\
\hline Fruit borer & $\begin{array}{l}\text { Strymon basilides Geyer (Lepidoptera: } \\
\text { Lycaenidae) }\end{array}$ & 24.5 & Minor \\
\hline Midget & $\begin{array}{l}\text { Elaphria nucicolora Guenee (Lepidoptera: } \\
\text { Noctuidae) }\end{array}$ & 12.2 & Minor \\
\hline
\end{tabular}


In the agroforestry system multistoried crop plants act as secure habitat for pest, predator and pollinator insects. In the studied agroforestry area, Hemiptoriod insects were most abundant on different crops. The results agreed with Amin et al. (2015) who studied the insect abundance and diversity in a mango based agroforestry in Bangladesh and found that the Hemiptera were most abundant (59.8\%). Namni et al. (2017) observed the highest abundance of hopper compared to other insects in a mango based agroforestry.

Table 4. Taxonomic profile of predator insects and their abundance in the agroforestry area during July 2015 to June 2016

\begin{tabular}{|c|c|c|}
\hline Predator insect & Taxonomic profile & Abundance \\
\hline Preying mantid & Mantis religiosa Linnaeus (Dictyoptera: Mantidae) & $0.8 \mathrm{c}$ \\
\hline Dragon fly & $\begin{array}{l}\text { Aeshna verticalis Hagen (Odonata: Aeshnidae) } \\
\text { Stylurus notatus Rambur (Odonata:Gomphidae) } \\
\text { Orthetrum glaucum Brauer (Odonata:Libellulidae) }\end{array}$ & $\begin{array}{l}1.6 a b \\
- \\
-\end{array}$ \\
\hline Damsel fly & $\begin{array}{l}\text { Coenagrion sp. Kirby (Odonata: Coenagrionidae) } \\
\text { Lestes vidua Hagen (Odonata:Lestidae) }\end{array}$ & $\begin{array}{l}1.2 \mathrm{ab} \\
-\end{array}$ \\
\hline Assassin bug & $\begin{array}{l}\text { Rhinocoris segmentarius Germar (Hemiptera: } \\
\text { Reduviidae) } \\
\text { Sinea diadema Fabricius (Hemiptera: Reduviidae) }\end{array}$ & $\begin{array}{l}1.0 \mathrm{bc} \\
-\end{array}$ \\
\hline Pirate bug & Orius insidiosus Say (Hemiptera: Anthocoridae) & $0.8 \mathrm{c}$ \\
\hline Lady bird beetle & $\begin{array}{l}\text { Coccinella septempunctata Linnaeus (Coleoptera: } \\
\text { Coccinellidae) } \\
\text { Coccinella transversalis Fabricius (Coleoptera: } \\
\text { Coccinellidae) } \\
\text { Menochilus sexmaculatus Fabricius (Coleoptera: } \\
\text { Coccinellidae) }\end{array}$ & $\begin{array}{l}2.2 \mathrm{ab} \\
- \\
-\end{array}$ \\
\hline Ground beetle & $\begin{array}{l}\text { Calosoma scrutator Fabricius (Coleoptera: } \\
\text { Carabidae) }\end{array}$ & $1.2 \mathrm{bc}$ \\
\hline Tiger beetle & Cicindela ocellata Klug (Coleoptera: Carabidae) & $1.3 \mathrm{ab}$ \\
\hline Ant & $\begin{array}{l}\text { Formica rubra Linnaeus (Hymenoptera: Formicidae) } \\
\text { Camponotus compressus Fabricius (Hymenoptera: } \\
\text { Formicidae) } \\
\text { Solenopsis geminata Fabricius (Hymenoptera: } \\
\text { Formicidae) }\end{array}$ & $\begin{array}{l}2.5 \mathrm{a} \\
- \\
-\end{array}$ \\
\hline Wasp & $\begin{array}{l}\text { Polistes dominula } \text { Christ (Hymenoptera: Vespidae) } \\
\text { Vespula vulgaris Linnaeus (Hymenoptera: Vespidae) }\end{array}$ & $\begin{array}{l}0.8 \mathrm{c} \\
-\end{array}$ \\
\hline Green lace wing & $\begin{array}{l}\text { Chrysoperla carnea Stephens (Neuroptera: } \\
\text { Chrysopidae) }\end{array}$ & $1.1 \mathrm{bc}$ \\
\hline
\end{tabular}


The findings indicated that the Hemipteroid pests were perhaps dominant on citrus, mango and pineapple during cooler and dry season. Our findings were in concurrence with Kaushik et al. (2012) and Kannan and Rao (2000) who observed significant abundance of hopper on mango plants. The plant species diversity in the agroforestry may have influenced the survival and abundance of insects by modifying the microclimate (Ram et al., 1989). Ram et al. (1989) reported that crop species sometimes create favorable conditions for pest incidence and damage.

There were 20 species of predator insects (Table 4) belonging to 13 families. Their abundance ranged from 0.8 to $2.5 / 40$ sweeps and the results differed significantly $(\mathrm{p}<0.01)$. The ants were most abundant followed by lady bird beetle, dragon fly, tiger beetle, ground beetle, damsel fly, green lacewing and assassin bug. The preying mantid, pirate bug and wasp had statistically similar and lowest abundance. This finding agreed with Amin et al. (2015) who reported that ants had highest abundance compared to others in a mango based agroforestry in Bangladesh.

Data expressed as mean and means per insect group are taken from 40 sweeps per total collection. Means within a column followed by same letter(s) are not significantly different (DMRT, $P \leq 0.05$ ). Dashes indicate no information

Nineteen species of insects under 12 families in 4 orders (Coleoptera, Lepidoptera, Hymenoptera and Diptera) were found as pollinators (Table 5). Their abundance varied from 1.7 to $5.1 / 40$ sweeps and the results differed significantly $(\mathrm{p}<0.001)$. Honey bee and horse fly showed the highest and lowest abundance, respectively. Amin et al. (2015) found 8 species of insects belonging to 7 families in 3 orders as pollinator in a mango based agroforestry area in Bangladesh. Fajardo et al. (2008) reported 21 species in five orders as insect pollinators of mango in Philippines. Sung et al. (2006) found 39 insect species as pollinators of mango in Southern Taiwan. Uddin et al. (2012) observed five species of insects in the order Diptera and Hymenoptera as pollinator of mango in Bangladesh.

Table 5. Taxonomic profile of pollinator insects along with their abundance in the agroforestry area during July 2015 to June 2016

\begin{tabular}{|c|c|c|c|c|}
\hline \multirow{2}{*}{$\begin{array}{l}\text { Insect pollinator } \\
\text { Epilachna beetle }\end{array}$} & \multicolumn{3}{|l|}{ Taxonomic profile } & \multirow{2}{*}{$\begin{array}{c}\text { Abundance } \\
2.6 \text { be } \\
-\end{array}$} \\
\hline & $\begin{array}{l}\text { Epilachna dodecastigma } \\
\text { Coccinellidae) }\end{array}$ & Wied & (Coleoptera: & \\
\hline & $\begin{array}{l}\text { Epilachna vigintioctopunctata } \\
\text { Coccinellidae) }\end{array}$ & Fabricius & (Coleoptera: & \\
\hline $\begin{array}{l}\text { Red pumpkin } \\
\text { beetle }\end{array}$ & $\begin{array}{l}\text { Aulacophora } \quad \text { foveicollis } \\
\text { Galerucidae) }\end{array}$ & Lucas & (Coleoptera: & $2.7 \mathrm{be}$ \\
\hline Lemon butterfly & \multicolumn{3}{|c|}{ Papilio demoleus Linnaeus (Lepidoptera: Papilionidae) } & $3.7 \mathrm{ad}$ \\
\hline Swallow tail & \multicolumn{3}{|c|}{ Papilio polytis Linnaeus (Lepidoptera: Papilionidae) } & 2.5 be \\
\hline
\end{tabular}




\begin{tabular}{|c|c|c|}
\hline Insect pollinator & Taxonomic profile & Abundance \\
\hline \multicolumn{3}{|l|}{ butter fly } \\
\hline $\begin{array}{l}\text { Four footed } \\
\text { butter fly }\end{array}$ & Junonia sp. Hubner (Lepidoptera: Nymphalidae) & $2.2 \mathrm{de}$ \\
\hline $\begin{array}{l}\text { Monarch } \\
\text { butterfly }\end{array}$ & Danus plexippus Linnaeus (Lepidoptera: Nymphalidae) & $1.9 \mathrm{de}$ \\
\hline $\begin{array}{l}\text { Sulphur butter } \\
\text { fly }\end{array}$ & Colias eurytheme Boisduval (Lepidoptera: Pieridae) & $4.1 \mathrm{ac}$ \\
\hline \multirow[t]{3}{*}{ Honey bee } & Apis mellifera Linnaeus (Hymenoptera: Apidae) & $5.1 \mathrm{a}$ \\
\hline & Apis cerana Fabricius (Hymenoptera: Apidae) & - \\
\hline & Apis dorsata Fabricius (Hymenoptera: Apidae) & - \\
\hline Carpenter bee & Xylocopa pubescens Spinola (Hymenoptera: Apidae) & 2.6 be \\
\hline \multirow[t]{2}{*}{ Wasp } & Polistes dominula Christ (Hymenoptera: Vespidae) & $1.9 \mathrm{de}$ \\
\hline & Vespula vulgaris Linnaeus (Hymenoptera: Vespidae) & - \\
\hline House fly & Musca domestica Linnaeus (Diptera: Muscidae) & 2.9 be \\
\hline Horse fly & Tabanus sp. Linnaeus (Diptera: Tabanidae) & $1.7 \mathrm{e}$ \\
\hline Blow fly & $\begin{array}{l}\text { Calliphora erythrocephala Meigen (Diptera: } \\
\text { Calliphoridae) }\end{array}$ & 2.6 be \\
\hline Syrphid fly & Syrphid sp. Linnaeus (Diptera: Syrphidae) & $4.3 \mathrm{ab}$ \\
\hline Fruit fly & Bactrocera dorsalis Hendel (Diptera: Tephritidae) & $2.3 \mathrm{ce}$ \\
\hline
\end{tabular}

Data expressed as mean and means per insect group are taken from 40 sweeps per total collection. Means within a column followed by same letter(s) are not significantly different (DMRT, $P \leq 0.05$ ). Dashes indicate no information.

The variation of the insect species abundance among pest, predator and pollinator in different countries and different regions of a country is due to climatic conditions, host plants and habitat management. In the present study, relative abundance of the insect pest species on citrus, mango and pineapple showed variation, and the abundance of predator and pollinator insect species also differed significantly. The predator and pollinator insects may have got secure habitat because of the presence of different plant species in the agroforestry system and they showed adequate abundance. Expansion of agroforestry technology could provide habitat for restoration of the beneficial insects, but information on the abundance and damage threshold of the insect pest species is very important prior to expand this technology in any locality (Epila, 1988). So, plant species combinations must be on the basis of least favorable conditions for the survival and multiplication of major pest species. 


\section{ACKNOWLEDGMENT}

This study was funded by the Ministry of Science and Technology, Government of the Peoples' Republic of Bangladesh to whom the authors are very grateful.

\section{REFERENCES}

Amin, M.R., Namni, S., Miah, M.R.U., Miah, M.G., Zakaria, M., Suh, S.J., and Kwon, Y.J. (2015). Insect inventories in a mango-based agroforestry area in Bangladesh: foraging behavior and performance of pollinators on fruit set. Entomological Research, 45, $217-$ 224.

Anitha, K.D., Lakshmi, B.K.M., Reddy, G.S., and Reddy, M.L. (2009). Influence of abiotic factors on the incidence of hopper and chemical control strategies in mango. Karnataka Journal of Agricultural Sciences, 22, 601-602.

Bugg, R.L., and Waddington, C. (1994). Using cover crops to manage arthropod pests of orchard: a review. Agriculture Ecosystem and Environment, 50, 11-28.

Debinski, D.M., and Holt, R.D. (2000). A survey and overview of habitat fragmentation experiments. Conservation Biology, 14, 342-355.

Dwivedi, S.C., Singh, S.M.K., and Katiyar, R.R. (2003). Seasonal incidence of insect pests associated with mango crop. Annals of Plant Protection Science, 16, 159-162.

Epila, J.S.O. (1988). Wind, crop pests and agroforestry design. Agriculture System, 26, 99110.

Farjado, A.C., Medin, J.R., Opina, O.S., and Cervancia, C.R. (2008). Insect pollinators and floral visitors of mango (Mangifera indicaL. cv. Carabao). The Philippine Agricultural Scientist, 91, 372-382

Kannan, M., and Rao, N.V. (2000). Seasonal incidence of lepidopteran pests in relation to weather parameters in mango Mangifera indica. Crop Research Hisar, 33, 198-203.

Kaushik, D.K., Baraiha, U., Thakur, B.S., and Parganiha, O.P. (2012). Pest complex and their succession on mango (Mangifera indica) in Chhattisgarh, India. Plant Archives, 12, 303-306.

Namni, S., Amin, M.R., Miah, M.R.U., Rahman, M.F., and Suh, S.J. (2017). Role of weather parameters on seasonal abundance of insects in a mango-based agroforestry in Bangladesh, with particular reference to mango hopper. Bangladesh Journal of Agricultural Research, 42, 197-205.

Ram, S., Gupta, M.P., and Patil, B.D. (1989). Pest management in fodder cowpea (Vigna unguiculata L. Walp.) through mixed and intercropping in India. Tropical Pest Management, 33, 345-347.

Sung, H.I., Lin, M.Y., Chang, C.H., and Chen, W.S. (2006). Pollinators and their behaviors on mango flowers in Southern Taiwan. Formosan Entomologist, 26, 161-170.

Uddin, M.A., Waliullah, M.H., and Akhter, M.S. (2012). Survey, collection and identification of different pollinators of mango. Annual Research Report, Bangladesh Agricultural Research Institute, Gazipur, Bangladesh, pp. 14-17. 